\title{
Front Matter: Volume 10856
}

, "Front Matter: Volume 10856," Proc. SPIE 10856, Diseases in the Breast and Reproductive System V, 1085601 (17 May 2019); doi:

$10.1117 / 12.2531192$

SPIE. Event: SPIE BiOS, 2019, San Francisco, California, United States 


\title{
Diseases in the Breast and Reproductive System V
}

\author{
Melissa C. Skala \\ Paul J. Campagnola \\ Darren M. Roblyer \\ Editors
}

2 February 2019

San Francisco, California, United States

Sponsored and Published by

SPIE

Volume 10856 
The papers in this volume were part of the technical conference cited on the cover and title page. Papers were selected and subject to review by the editors and conference program committee. Some conference presentations may not be available for publication. Additional papers and presentation recordings may be available online in the SPIE Digital Library at SPIEDigitalLibrary.org.

The papers reflect the work and thoughts of the authors and are published herein as submitted. The publisher is not responsible for the validity of the information or for any outcomes resulting from reliance thereon.

Please use the following format to cite material from these proceedings:

Author(s), "Title of Paper," in Diseases in the Breast and Reproductive System V, edited by Melissa C. Skala, Paul J. Campagnola, Darren M. Roblyer, Proceedings of SPIE Vol. 10856 (SPIE, Bellingham, WA, 2019) Seven-digit Article CID Number.

ISSN: 1605-7422

ISSN: $2410-9045$ (electronic)

ISBN: 9781510623545

ISBN: 9781510623552 (electronic)

Published by

SPIE

P.O. Box 10, Bellingham, Washington 98227-0010 USA

Telephone +1 3606763290 (Pacific Time) · Fax +1 3606471445

SPIE.org

Copyright @ 2019, Society of Photo-Optical Instrumentation Engineers.

Copying of material in this book for internal or personal use, or for the internal or personal use of specific clients, beyond the fair use provisions granted by the U.S. Copyright Law is authorized by SPIE subject to payment of copying fees. The Transactional Reporting Service base fee for this volume is $\$ 18.00$ per article (or portion thereof), which should be paid directly to the Copyright Clearance Center (CCC), 222 Rosewood Drive, Danvers, MA 01923. Payment may also be made electronically through CCC Online at copyright.com. Other copying for republication, resale, advertising or promotion, or any form of systematic or multiple reproduction of any material in this book is prohibited except with permission in writing from the publisher. The CCC fee code is 1605$7422 / 19 / \$ 18.00$.

Printed in the United States of America by Curran Associates, Inc. under license from SPIE.

Publication of record for individual papers is online in the SPIE Digital Library.

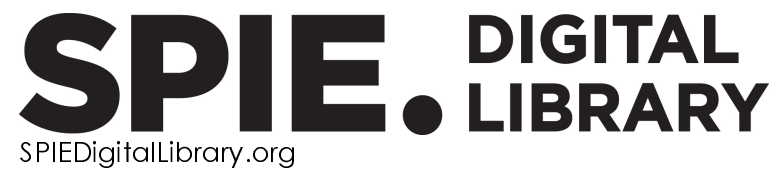

Paper Numbering: Proceedings of SPIE follow an e-First publication model. A unique citation identifier (CID) number is assigned to each article at the time of publication. Utilization of CIDs allows articles to be fully citable as soon as they are published online, and connects the same identifier to all online and print versions of the publication. SPIE uses a seven-digit CID article numbering system structured as follows:

- The first five digits correspond to the SPIE volume number.

- The last two digits indicate publication order within the volume using a Base 36 numbering system employing both numerals and letters. These two-number sets start with $00,01,02,03,04$, 05, 06, 07, 08, 09, OA, OB ... 0Z, followed by 10-1Z, 20-2Z, etc. The CID Number appears on each page of the manuscript. 


\title{
Contents
}

\author{
$\checkmark \quad$ Authors \\ vii Conference Committee
}

\section{OBSTETRICS AND GYNECOLOGY}

1085603 In vitro characterization of collagen organization in the human cervix using polarizationsensitive optical coherence tomography (PS-OCT) [10856-2]

1085605 In vivo multiphoton imaging of an ovarian cancer mouse model [10856-4]

BREAST CANCER SURGERY TECHNOLOGIES

10856 OF Non-contact imaging of breast surface for breast surgical planning [10856-14]

10856 ol Snapshot hyperspectral imaging for detection of breast tumors in resected specimens [10856-17]

\section{POSTER SESSION}

$10856 \mathrm{OL}$ A novel multimodal optical imaging device for cervical cancer screening and diagnosis [10856-20] 
Proc. of SPIE Vol. 10856 1085601-4

Downloaded From: https://www.spiedigitallibrary.org/conference-proceedings-of-spie on 26 Apr 2023 Terms of Use: https://www.spiedigitallibrary.org/terms-of-use 


\section{Authors}

Numbers in the index correspond to the last two digits of the seven-digit citation identifier (CID) article numbering system used in Proceedings of SPIE. The first five digits reflect the volume number. Base 36 numbering is employed for the last two digits and indicates the order of articles within the volume. Numbers start with 00, 01, 02, 03, 04, 05, 06, 07, 08, 09, OA, OB...0Z, followed by 10-12, 20-2Z, etc.

Anumba, Dilichukwu O., 03

Barton, Jennifer K., 05

Brackstone, Muriel, OF

Cai, Kathy Q., 05

Carson, Jeffrey J. L., OF

Chamson-Reig, Astrid, OF

Connolly, Denise C., 05

Dijkstra, J., Ol

Diop, Mamadou, OF

Dzyubachyk, O., Ol

Eggermont, J., 이

Fariña-Sarasqueta, A., Ol

Gordon, Shiri, OL

Koevary, Jennifer W., 05

Landesman, Ilan, $\mathrm{OL}$

Levi, Effi, OL

Li, Wei, 03

Matcher, Stephen J., 03

Mieog, J. S. D., Ol

Narice, Brenda F., 03

Rice, Faith F., 05

Sawyer, Travis W., 05

Seadia, Oz, OL

Tong, Olivia L. H., OF

Vahrmeijer, A. L., 이

van Manen, L., Ol

Yip, Lawrence C. M., OF 
Proc. of SPIE Vol. 10856 1085601-6

Downloaded From: https://www.spiedigitallibrary.org/conference-proceedings-of-spie on 26 Apr 2023 Terms of Use: https://www.spiedigitallibrary.org/terms-of-use 


\section{Conference Committee}

Symposium Chairs

James G. Fujimoto, Massachusetts Institute of Technology (United States)

R. Rox Anderson, Wellman Center for Photomedicine, Massachusetts General Hospital (United States) and Harvard Medical School (United States)

Symposium Co-chairs

Jennifer K. Barton, The University of Arizona (United States)

Wolfgang Drexler, Medical University of Vienna (Austria)

Program Track Chairs

Brian Jet-Fei Wong, Beckman Laser Institute and Medical Clinic, University of California, Irvine (United States)

Eva Sevick, The University of Texas Health Science Center at Houston (United States)

\section{Conference Chairs}

Melissa C. Skala, University of Wisconsin-Madison (United States)

Paul J. Campagnola, University of Wisconsin-Madison (United States)

Darren M. Roblyer, Boston University (United States)

Conference Program Committee

Ji-Xin Cheng, Boston University (United States)

Anita Mahadevan-Jansen, Vanderbilt University (United States)

Andrew M. Rollins, Case Western Reserve University (United States)

Bruce J. Tromberg, Beckman Laser Institute and Medical Clinic (United States)

Kevin W. Eliceiri, University of Wisconsin-Madison (United States)

Session Chairs

1 Obstetrics and Gynecology

Thomas D. O'Sullivan, University of Notre Dame (United States)

2 Breast Cancer Biology

Darren M. Roblyer, Boston University (United States) 
3 Optimizing Cancer Treatment

Mark C. Pierce, Rutgers, The State University of New Jersey (United States)

4 Breast Cancer Surgery Technologies

Alex J. Walsh, Morgridge Institute for Research (United States)

Timothy J. Muldoon, University of Arkansas (United States) 